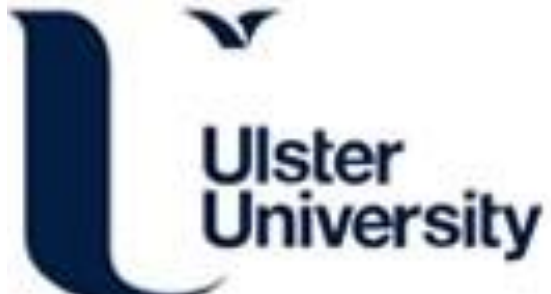

\section{The use of social media (some) as a learning tool in healthcare education: An integrative review of the literature}

Goode, D., \& Scott, N. (2020). The use of social media (some) as a learning tool in healthcare education: An integrative review of the literature. Nurse Education Today, 87, [104357].

https://doi.org/10.1016/j.nedt.2020.104357

Link to publication record in Ulster University Research Portal

\section{Published in:}

Nurse Education Today

Publication Status:

Published (in print/issue): 30/04/2020

DOI:

10.1016/j.nedt.2020.104357

\section{Document Version}

Author Accepted version

\section{General rights}

Copyright for the publications made accessible via Ulster University's Research Portal is retained by the author(s) and / or other copyright owners and it is a condition of accessing these publications that users recognise and abide by the legal requirements associated with these rights.

\section{Take down policy}

The Research Portal is Ulster University's institutional repository that provides access to Ulster's research outputs. Every effort has been made to ensure that content in the Research Portal does not infringe any person's rights, or applicable UK laws. If you discover content in the Research Portal that you believe breaches copyright or violates any law, please contact pure-support@ulster.ac.uk. 


\section{Journal Pre-proof}

The use of social media (some) as a learning tool in healthcare education: An integrative review of the literature

Natalie Scott, Debbie Goode

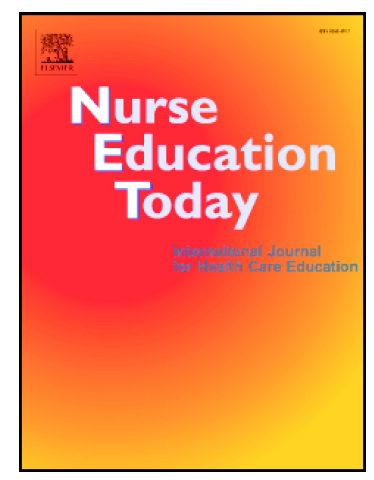

PII: $\quad$ S0260-6917(19)31233-X

DOI: $\quad$ https://doi.org/10.1016/j.nedt.2020.104357

Reference: $\quad$ YNEDT 104357

To appear in: $\quad$ Nurse Education Today

Received date: $\quad 11$ August 2019

Revised date: $\quad 26$ November 2019

Accepted date: $\quad 27$ January 2020

Please cite this article as: N. Scott and D. Goode, The use of social media (some) as a learning tool in healthcare education: An integrative review of the literature, Nurse Education Today(2020), https://doi.org/10.1016/j.nedt.2020.104357

This is a PDF file of an article that has undergone enhancements after acceptance, such as the addition of a cover page and metadata, and formatting for readability, but it is not yet the definitive version of record. This version will undergo additional copyediting, typesetting and review before it is published in its final form, but we are providing this version to give early visibility of the article. Please note that, during the production process, errors may be discovered which could affect the content, and all legal disclaimers that apply to the journal pertain.

(C) 2020 Published by Elsevier. 
THE USE OF SOCIAL MEDIA (SOME) AS A LEARNING TOOL IN HEALTHCARE EDUCATION: AN INTEGRATIVE REVIEW OF THE LITERATURE

This is to certify that there has been no external funding source for this review and that there is no conflict of interests.

Mrs Natalie Scott

Staff Nurse

Northern Health and Social Care Trust

Dr Debbie Goode * Corresponding author Lecturer in Nursing

Ulster University

Northland Road

L/Derry

BT487JL

Work 02871675219 Mobile 07966171488

D.Goode@ulster.ac.uk 
Word Count 4483/4500 including abstract and keywords but excluding refs as per guidelines from NET

The use of social media (SoMe) as a learning tool in healthcare education: an integrative review of the literature 


\section{Abstract}

Objectives: The exponential rise of social media (SoMe) has transformed how people connect, learn, and network. The use of SoMe in health education is in its infancy. The objective of the review was to examine the use of SoMe by healthcare students, professionals and educators to ascertain if the use of SoMe enhanced the learning experience.

Design: An integrative literature review was completed in February 2019.

Data sources: Three databases were used to facilitate the literature search (Medline (Ovid), Cinahl, and Scopus).

Review methods: Inclusion and exclusion criteria for the literature search were applied and PRISMA guidelines followed. The search retrieved 316 citations. Forty-seven duplicate articles were removed at this stage. Titles and abstracts were screened and 215 excluded as they were not relevant. The remaining articles were assessed for eligibility and 37 were excluded for not meeting the review requirements.

Results: Critical Appraisal Skills Programme (CASP 2019) checklists primarily guided the critique of the literature, with the Caldwell et al. (2011) approach used to supplement the critique of health-related research studies. 17 research studies are included in this review. Themes were developed using Braun and Clarke's (2006) approach. Five reoccurring themes emerged: communication and collaboration, a source of reference, personal development, pitfalls and ethical concerns.

Conclusions: This review provides a synthesis of SoMe use in healthcare education. SoMe is an excellent educational resource which can provide advantages in education. Areas of concern were noted and the need for improved policy and guidance highlighted. Further research and education on SoMe use in healthcare education is essential for educators, students and practitioners.

262 words $/ 300$

Keywords: Nurse Education, Healthcare, Social Media (SoMe), Communication. 


\section{Introduction}

Communication is essential in healthcare to both build and sustain relationships and yet in today's society, traditional communication methods are no longer deemed solely appropriate (Arrigoni et al. 2016). The rise of social media (SoMe) has transformed how people connect, learn and network (De Gagne et al. 2018). The development of Web 2.0 has changed the way we use the internet, due to the availability and accessibility of more immediate user interaction platforms (O'Reilly 2005). This has coincided with year-on-year increases totalling 4.021 billion internet users and 3.196 billion global SoMe users (Global Digital Report 2018). This emerging phenomenon has impacted all areas of civilisation, particularly the private and professional lives of many healthcare professionals (Arrigoni et al. 2016).

The term 'Social media' refers to the use of online tools created for social communication exchanges between users (Nyangeni et al. 2015). SoMe platforms are composed of three elements: content (pictures, videos and online messages), groups (needed for social interactions), and the internet (Lahti et al. 2017). SoMe encompasses a wide range of digital applications including blogs, microblogs (Twitter), videos and pictures (YouTube and Instagram), social networking sites (Facebook), wikis (Wikipedia), instant messaging (WhatsApp and Facebook messenger) and virtual worlds (Second Life) (Nyangeni 2015; Ross 
and Myers 2017). Facebook, Twitter and YouTube are recognised as the most popular and widely used SoMe platforms in nursing education (Booth 2015).

Almost all healthcare organisations have a visible SoMe presence (Gagnon 2015); its use in education, however, is still developing (Price et al. 2018). A heavily debated and controversial topic, SoMe use in health education remains a challenge (Jones et al. 2016b). Ethical concerns, including the potential for privacy and confidentiality breaches, are prevalent (Maloney et al. 2014; Booth 2015). However, Price et al. (2018) argue that a lack of clear policy is hindering the use of what could be a beneficial teaching tool. The National Institute for Health and Care Excellence (2016), and the Nursing and Midwifery Council (2018) have recently offered guidance on acceptable SoMe use. When used appropriately, SoMe is a promising tool that enhances communication, provides information, and helps promote health-related resources (Sinclair et al 2015, Lofters et al. 2016).

\section{Problem Identification}

There are several problems that have been identified in the use of SoMe in healthcare education. According to Tuckett and Turner (2016), it is not clear if SoMe enhances learning, or merely supplements traditional teaching methods. Yet, over $80 \%$ of healthcare students are millennials, who do not know a time without the internet (Duke et al. 2017), suggesting the need for educationalists to review teaching styles and adapt curricula to evolve with ever-growing technological advances (Lahti et al. 2017). Stephens and Gunther (2016) argue that millennials have different brain structures and distinctive learning styles to digital immigrants. Booth (2015) suggests that many educators are unclear of the usefulness of SoMe, or how to implement such a change into their teaching. As SoMe use in health education is in its infancy, there is a dearth of research on its effectiveness (Maloney et al. 
2014; Gagnon 2015; Lahti et al. 2017). Leading to the question: does the use of SoMe enhance the learning experience of health professionals? The purpose of this integrative review is to provide a thorough synthesis of SoMe use in healthcare education, highlight gaps, and offer recommendations for education, practice, policy and research.

\section{Methods}

An integrative review was chosen as the review method as it allows a wide sampling frame and the inclusion of a broad range of literature from a variety of research methods. The review process followed the structured methodology outlined by Whittemore and Knafl (2005): problem identification, literature search, data evaluation and analysis and presentation.

\section{Literature search}

The literature search was carried out using Medline (Ovid), Cinahl, and Scopus databases. Keywords are illustrated in Table 1, following guidance from a subject-specific librarian.

\section{Insert table 1 here}

Search modes were extended to 'apply equivalent subjects' and 'apply related words.' with the Boolean operators 'AND' and 'OR' to produce more focused and productive results (Ely and Scott 2007). As suggested by Parahoo (2014), inclusion and exclusion criteria were established (Table 2), which restricted searches to the English language between 2014 and 2019. As SoMe use in education is in its infancy, a review of published research in the past five years was considered a suitable timeframe to produce relevant results. 


\section{Insert table 2 here}

PRISMA guidelines (Figure 1) were applied to select the chosen literature (Liberati et al. 2009). The search identified 316 citations. 269 articles remained after the duplicates were excluded. Sources were then screened by title and abstract, and 215 unsuitable articles were excluded. Reasons for exclusion include but are not limited to: patients use of SoMe, healthy eating videos, patient blogs, and peer network support. Subsequently, 54 full-text articles were independently assessed for eligibility. Of the remaining articles, 37 were excluded for reasons including, but not limited to: advancements in technology, smartphone use, and WhatsApp use to connect burns patients. This resulted in 17 articles being implemented into the final review.

\section{Insert figure 1 here}

\section{Data evaluation and analysis}

To assist in the process of data evaluation (Whittemore and Knafl 2005), the SALSA (Search, AppraisaL, Synthesis and Analysis) approach (Grant and Booth 2009) was used to identify and distinguish the type of research study. The research selected utilised qualitative and quantitative approaches. Data analysis followed the Critical Appraisal Skills Programme (CASP 2019) checklists primarily guided the critique of the literature, with the Caldwell et al. (2011) approach used to supplement the critique of health-related research studies. Data were extracted and collated into tabular form, with similar data for ease of categorisation and comparison. A literature summary table is displayed in Table 3.

\section{Insert table 3 here}


Once the data was reduced to tabular form, further thematic analysis was completed using Braun and Clarke's (2006) six-phase guide: familiarisation with the data, generation of initial codes, search for themes, review themes, define themes, write up.

\section{A critical review of the literature}

This integrative review of the literature presented commonalities, and five reoccurring themes emerged (Table 4).

\section{Insert table 4 here}

\section{Communication and Collaboration}

Social media as an educational tool in healthcare teaching has been identified to improve collaboration and peer connections (Maloney et al. 2014; Booth 2015; Gagnon 2015; Stephens and Gunther 2015; Duke et al. 2017; Pimmer et al. 2018; Price et al. 2018; Tubaishat 2018; Warshawski et al. 2018). This review confirms that Facebook and Twitter are the main SoMe platforms that are currently used in health education. Maloney et al. (2014) reported that students create Facebook groups for continuous online interactions and to build support networks. Facebook provided a space where students shared ideas, offered advice, asked questions and availed of reminders, at any time of the day. Correspondingly, Tubaishat (2018) noted that $84.4 \% \quad(n=128)$ of participants viewed Facebook as a necessity for enhancing communication. Facebook provided an avenue for peer learning, where interactions were enabled, and students could exchange thoughts, worries and educational experiences (Tubaishat 2018). As over $80 \%$ of healthcare students are millennials, and over $90 \%$ of $18-29$-year olds are active Facebook users (Ross and Myers 2017), students used a familiar tool to make contributions, from their online place of choice. 
Ross and Myers (2017) suggested that when communication occurred in non-threatening environments user involvement increased and users would participate with ease at their own pace.

Price et al. (2018) concurred, stating online interactions created a more collaborative learning approach; offering and receiving feedback encouraged the growth of peer support networks. It has been proposed that these exchanges are linked to increased confidence levels as students benchmark their levels of understanding against information gathered from these interactions (Price et al. 2018). Gagnon (2015) contended that by using Twitter, all class members could participate in online discussions, not only those who speak out in class. These results echo those reported by Tubaishat (2018), who suggested that online discussions reduced the stress and anxiety levels of individuals who are not comfortable with face-to-face interactions. Similarly, it is suggested that by the use of SoMe, students become empowered, as they begin to take more control over their learning (Tubaishat 2018).

Conversely, Jones et al. (2016a) stated that quieter students are dominated and overpowered by assertive students when using SoMe just as they are in the classroom. A common issue noted was the relationship between online communication and social relationships, with $93 \%$ of young adults having an online presence and $32 \%$ using of them using SoMe to build social connections (Maloney et al. 2014). It is not surprising that these tools are also used for the same purpose at university. Being part of online groups provides students with a sense of belonging, which can ease their adjustment into university life (Maloney et al. 2014). Correspondingly, Stephen and Gunthers (2016) reported that Twitter helped build social relationships both inside and outside the classroom. These connections 
are also linked with improved psychological wellbeing (Maloney et al. 2014). Similarly, Pimmer et al. (2018), argued that WhatsApp use was associated with a reduction in perceived feelings of isolation. Researchers claimed that an increase in the use of WhatsApp during clinical placements led to increased engagement with their peers and lower feelings of isolation in professional situations.

Social media also improves communication between students and tutors. Facebook provides a platform where students can ask questions, clarify issues identified post-class, and receive feedback from their lecturers (Maloney et al. 2014). Price et al. (2018) argue that instantaneous feedback is associated with increased confidence and motivation levels. Similarly, Stephens and Gunther (2016) report that instant feedback has become a requirement for millennial students as they are reluctant to participate in discussions in its absence. They suggest that students prefer little or no face-to-face communication, and are more comfortable interacting with lecturers online (Tubaishat 2018). Similarly, Duke et al. (2017) contest that interactions of this nature can improve schooling. They affirmed that by using SoMe, lecturers can easily identify what works well and what does not, and amend their teaching plans to keep in line with current trends. However, a contrasting viewpoint by Maloney et al. (2014) is that lecturers should remain professionally distanced from students. Private life should be just that, and if blurred within boundaries of what information students consider is appropriate to share online, may lead to lecturers losing their credibility.

SoMe has been reported as a useful tool when students are struggling to communicate effectively. Booth (2015) examined the tweets of 189 nursing students over a collective sixday period and identified that Twitter was used as a coping mechanism. Stephens and 
Gunthers (2016) claim that millennial students are susceptible to stress as a result of their poorly developed coping techniques, and little experience dealing with confrontation. Twitter interactions provided comfort and reassurance when the students expressed concerns, worries and apprehensions about their course (Booth 2015). Similarly, Warshawski et al. (2018), compared SoMe platforms and other support forums. Results showed an increase in both strength and confidence levels as students released stress online and adopted new coping strategies. Conversely, findings from the same study linked SoMe use to high pre-test anxiety levels. It may be suggested that exposure to new knowledge or learning of peer stresses can increase anxiety levels. These findings, however, are inconsistent with much of the existing literature and may result from cultural differences in Israel about the nature of the information that is posted online.

To summarise, the majority of the research points to the enhancement of communication and teamwork when using SoMe in health education.

\section{A source of reference}

Having outlined social media's usefulness in communication, another key finding is its instant source of information. As SoMe was initially developed for social purposes, it is not surprising that many critics question the reliability and precision of the educational information sourced from it (Booth 2015). However, social media's growth coincides with the availability of easy-to-access, up to date, evidence-based information at the click of a button. Blogs especially are effective tools that can accommodate information sharing, as users can post asynchronous messages, reply to posts, and engage in discussions. Nedder et al. (2017), reported that blogs not only provide an avenue for link sharing among staff, but they also can notify users with regular updates when new information is available. An 
advantage being that users do not have to search for information, but that it is provided to them in real-time.

Similarly, Jones et al. (2016b) found that Twitter boosted the learning experience of its users. Twitter currently offers a wide range of health information and its integration into education can increase knowledge of health issues and specific diagnostics (Jones et al. 2016b). In addition, many health professionals are both accessible and willing to educate trainees during their student journey and beyond using SoMe (Jones et al. 2016b). Price et al. (2018) support this stating that Twitter use was linked to improved knowledge of nursing matters. The timely exchange of evidence-based information, without geographical barriers, encouraged users to gain a wider perspective of nursing, and indeed the field of healthcare in general.

According to Maloney et al. (2014) when SoMe is used in education it contributes to a more meaningful learning experience. YouTube and Facebook offer a huge selection of educational videos, interactive diagrams, real-life tasks and scenarios that are valuable learning tools for visual learners. Maloney et al. (2014), affirmed that YouTube promotes active learning for visual learners, as they began to apply new knowledge gained from these tools, which enhanced critical thinking and reflective skills. This finding is consistent with Stephens and Gunther (2016) who argued that instant tweet notifications provide valuable information, such as assignment reminders, course content, and keywords. The use of SoMe platforms enables the exchange of information outside the classroom, something that is useful to all class members. The use of SoMe can assist in the development of instantaneous learning for both students and registered health professionals.

\section{Personal Development}


So far, this thematic analysis has identified how SoMe in education enhances communication and is a platform for information exchanges. Closely linked to the previous theme, gathering and utilising relevant information can enhance personal and professional development. Twitter has been recognised as a tool that promotes academic gains by encouraging continuous, ongoing education (Gagnon 2015; Tuckett and Turner; Jones et al. 2016b; Price et al. 2018). A Twitter experiment by Gagnon (2015) reported that students found useful sources of information or "good follows" relating to their course. Using Twitter, students were encouraged to form academic accounts on Linkedln, a social networking site designed for professionals to connect. Likewise, Jones et al. (2016b) reported over $50 \%$ of students in their study follow a combination of nursing journals, nursing communities, nursing press and the National Health Service (NHS). As these communities are inclined to post new research, articles and online blogs, the academic knowledge of many active followers can also develop.

Furthermore, Tuckett and Turner (2016) reported that Twitter enhanced knowledge of specific health issues, and promoted public health campaigns. Twitter is also recognised as a successful adjunct to traditional learning and teaching methods. Gagnon (2015), suggests that Twitter encouraged interactions, enhanced active learning, and improved critical thinking and reasoning skills, (as users were confined to 140-character posts at the time of the study), ideas needed to be communicated succinctly. However, Stephens and Gunther (2016), proposed a contrasting view, suggesting that a small character limit was frustrating, as students could not participate in comprehensive, in-depth discussions.

A further aspect of personal development was suggested by Price et al. (2018), who argued that the wealth of online information encouraged students to critique both usefulness and 
reliability of the information. Likewise, Lahti et al. (2017) reported that Second Life (an online virtual world) helps to educate users on critical thinking and decision-making skills. Similarly, Jones et al. (2016a), stated that blogs are ideal to enhance clinical reflection; which is a vital skill for nurses to possess from an early point in their career. It is reported that blogs encourage education through dialogues, which are also designed to develop reasoning and rational thinking skills (Jones et al. 2016a). This prompted users to frequently reflect on how they work, and identify areas for improvement. Information obtained from SoMe may enhance professional skills, which may aid the transition from student to a registered health professional.

\section{Pitfalls of social media use}

Despite the promising benefits of social media as a pedagogical tool, many educationalists are still reluctant to use it due to the possibility of added distraction (Tubaishat 2018). Jones et al. (2016b) found that blogs can become a distraction as users often viewed them as another means of socialisation, and so its educational purpose may be lost. Correspondingly, Maloney et al. (2014) argued that SoMe already is a distraction to students and using it in education settings could intensify the problem, even with good intentions.

Another area of concern was raised by Tubaishat (2018), who claimed that SoMe contributed to procrastination and its use in education is related to lower academic successes. Similarly, Jones et al. (2016a) reported that SoMe reduced academic writing skills and encouraged plagiarism, as it becomes easier to copy and paste information online.

Improved communication was cited as one of the benefits of SoMe, however, Lofters et al. (2016) found that Facebook in healthcare failed to improve communication. Participants 
reported that the online group was unnecessary, added extra time to their already demanding schedules and that face-to-face communication was preferred. The same concerns were reported by Jones et al. (2016a), who also stated that students became distanced from their peers, and failed to create professional friendships. Another issue raised in the literature is the reluctance to change or to learn a new skill, which may inhibit SoMe working in education (Maloney et al. 2014; Stephens and Gunthers 2016). If unfamiliar with certain SoMe tools, students of all ages claim that they do not have the time to learn new skills, which may add to the stresses, difficulties and demands of already overworked students (Price et al. 2018).

An area that is relevant to health care professionals is confidentiality. Stephens and Gunthers (2016) argue that students are cautious about sharing ideas in public spaces as posts are open to misinterpretation, which can mislead and confuse the reader. This may cause cyberbullying or trolling, which may make students less likely to use SoMe for professional purposes (Booth 2015; Stephen and Gunthers 2016; Jones et al. 2016a). To summarise, potential pitfalls of SoMe use in education do exist. Though avoiding SoMe is not the answer; there are a plethora of learning opportunities when used correctly.

\section{Ethical and moral issues}

Having identified the advantages and disadvantages of social media use in education, the final theme related to ethical concerns. The NMC Code (2018), in a professional guidance paper, outlines the core values expected of nurses and midwives and has more recently integrated into their standards the importance of e-professionalism. This comes at a time when the growth of SoMe coincides with a surge in unprofessional online conduct (De Gagne et al. 2018). Over $60 \%$ of the articles analysed discussed the potential for 
misconduct. Common issues are the intentional and unintentional privacy and confidentiality breaches (Maloney et al. 2014; Nyangeni et al. 2015; Jones et al. 2016b; De Gagne et al. 2018; Tubaishat 2018). The challenge persists where health professionals fail to distinguish between their personal and professional lives online (Price et al. 2018). This may inadvertently lead to the disclosure of personal and private health-related information (Jones et al. 2016a), which can potentially identify patients and healthcare settings (Nyangeni et al. 2015). The trust of healthcare staff may be hindered, as well as the reputation of the industry itself (De Gagne et al. 2018). Breaches often have long term repercussions, resulting in instant dismissals and the withdrawal of licences (De Gagne et al. 2018)

Nyangeni et al. (2015), conducted semi-structured interviews with 12 nursing students in South Africa, who admitted knowingly using SoMe irresponsibly. Intimate videos and photos were posted online, without consent, and students manipulated patients to enhance their professional experiences. This study, although not unique, draws attention to the need for the imminent development of standard guidelines that outline responsible SoMe use worldwide. This is emphasised by De Gagne et al. (2018), who completed a descriptive, cross-sectional review of 230 nursing school websites. They reported that only $34.8 \%(n=80)$ had appropriate guidelines in place. This is an international concern and requires urgent action such as suitable guidelines that outline the consequences of misconduct. While, this may prove difficult due to the constant development of SoMe platforms and lack of resources to monitor its use, the importance of e-professionalism should not be underestimated (Price et al. 2018). Interestingly, Jones et al. (2016b) recommended that digital professionalism should become an essential nursing skill. Ethical issues are a concern 
for integrating SoMe use in education, but clear policies and guidelines on e-professionalism could help alleviate these concerns.

\section{Discussion}

This literature review focused on the use of SoMe as a promising platform to enhance learning in health education. However, further research is necessary using larger sample sizes, from multiple settings, using validated and reliable tools (Maloney et al. 2014; Tubaishat 2018) to formally measure and evaluate the use of a variety of SoMe tools in undergraduate and postgraduate settings to ascertain if it is the best method to support learning and information retention in healthcare education (Gagnon 2015; Lofters et al. 2016; Nedder et al. 2017).

Social media encourages communication and teamwork among its users. Research suggests these collaborations promote peer-learning, increase confidence levels, improve psychological well-being, and reduce professional isolation. However, it would be useful to examine how the use of SoMe in education can be transferred into professional careers (Nyangeni et al. 2015; Lahti et al. 2017; Nedder et al. 2017) and to report these findings to all healthcare settings to help to create or amend guidelines for acceptable use (Nyangeni et al. 2015).

Social media provides an instant source of information, from reputable online bodies, without geographical barriers. The academic information sourced from SoMe encourages professional development in the healthcare field. Despite this, some researchers claim SoMe in education is unnecessary, and a distraction for already overworked students. Training for educators on managing the benefits and issues concerned with SoMe use would 
be useful (Lahti et al. 2017; Duke et al. 2017; Price et al. 2018; Tubaishat 2018). Concerns around e-professionalism, privacy and confidentiality could be addressed within the training to further develop this promising tool in health education (Nyangeni et al. 2015; Booth 2015; Duke et al. 2017; De Gagne et al. 2018).

Common strengths identified from the studies selected included the use of data analysis packages for analysing results, which is recommended to enhance the reliability of quantitative research (Grey 2018). This type of computer software was used by Jones et al. (2016b), Duke et al. (2017), and Tubaishat (2018). Quantitative results with a P-value of $<0.05$, and a good Cronbach alpha score $(>0.70)$ indicate reliable results. These results were illustrated by Duke et al. (2017), Tubaishat (2018), and Pimmer et al. (2018).

Common limitations that were identified from the studies included small sample sizes, research from a single setting which limited the transferability and the generalisability of quantitative results to the population at large. Poor response rates are further limitations found in the studies, which have been recognised as a potential source of bias (Rindfuss et al. 2015). Williamson and Whittaker (2017) argue that convenience, non-random sampling is the least credible sampling method; a factor identified in several studies. Non-validated tools and statistically insignificant results are further limitations. These weaknesses make it difficult to draw significant conclusions on the effectiveness of SoMe in education.

The analysis from this review highlights the need for improved policies and guidelines worldwide so that all users can benefit from the readily available learning opportunities. Universal policies are crucial to avoid cyber incivility and to encourage digital professionalism (Tuckett and Turner 2016; De Gagne et al. 2018) The outcomes provided by SoMe are diverse, and research illustrates that using SoMe as an educational tool can 
enhance the learning experience of many healthcare professionals. Through education and support, all healthcare professionals should be informed on how to act when using social media, and when and where to engage with it in practice (Tuckett and Turner 2016).

\section{Conclusion}

The rapid and exponential growth of the internet, Web 2.0, and SoMe, in particular, has reformed how we communicate. This review delivers a thorough synthesis of SoMe use by healthcare students, professionals and educators in clinical practice and in third level settings. Findings determine that SoMe is an excellent educational resource that can enhance the learning experience of health professionals and can benefit both educationalists and healthcare students alike. SoMe has the potential to enhance communication, collaboration, personal development, as well as offering an up-to-date source of reference. SoMe use is linked to improved peer-learning, increased confidence levels, improved psychological well-being, and reduced professional isolation. Evidently, areas of concern were identified, including issues of e-professionalism, privacy and confidentiality. The need for improved policy and guidance should be addressed to ensure safe use. Further research and education on social media use in healthcare education is essential for educators, students and practitioners. 


\section{References}

Arrigoni, C., Alvaro, R., Vellone, E. and Vanzetta, M. (2016) Social media and nurse education: an integrative review of the literature. Journal of Mass Communication and Journalism, 6(1), 1-8.

Booth, R. (2015) Happiness, stress, a bit of vulgarity, and lots of discursive conversation: a pilot study examining nursing students' tweets about nursing education posted to Twitter. Nurse Education Today, 35(2), 322-327.

Braun, V. \& Clarke, V. (2006). Using thematic analysis in psychology. Qualitative Research in Psychology. 3, 77-101.

Caldwell, K., Henshaw, L. and Taylor, G. (2011) Developing a framework for critiquing health research: an early evaluation. Nurse Education Today, 31(8), 1-7.

Critical Appraisal Skills Programme (2019) CASP Qualitative Research Checklist. Available at: https://casp-uk.net/wp-content/uploads/2018/01/CASP-Qualitative-Checklist-2018.pdf [Accessed 04 March 2019].

De Gagne, J.C., Yamane, S.S., Conklin, J.L., Chang, J. and Kang, H.S. (2018) Social media use and cybercivility guidelines in U.S. nursing schools: a review of websites. Journal of Professional Nursing, 34(1), 35-41.

Duke, V.J.A., Anstey, A., Carter, S., Gosse, N., Hutchens, K.M. and Marsh, J.A. (2017). Social media in nurse education: utilization and e-professionalism. Nurse Education Today, 57(1), 8-13.

Ely, S. and Scott, I. (2007) Essential study skills for nursing. London: Elsevier.

Gagnon, K. (2015) Using Twitter in health professional education: a case study. Journal of Allied Health, 44(1), 25-33.

Global Digital Report. (2018) Global social media research summary 2019. Available at: https://www.smartinsights.com/social-media-marketing/social-media-strategy/new-globalsocial-media-research/ [Accessed 02 March 2019]. 
Grant, M.J. and Booth, A. (2009) A typology of reviews: an analysis of 14 review types and associated methodologies. Health Information and Libraries Journal, 26(2), 91-108.

Grey, D.E. (2018) Doing research in the real world. $4^{\text {th }}$ ed. London: SAGE Publications Ltd. Jones, K, Garrity, M.K., VanderZwan, K.J., Epstein, I. and de la Rocha, A.B. (2016a) To blog or not to blog: what do nursing faculty think? Journal of Nursing Education, 55(12), 683-689.

Jones, R., Kelsey, J., Nelmes, P., Chinn, N., Chinn, T. and Proctor-Childs, T. (2016b) Introducing Twitter as an assessed component of the undergraduate nursing curriculum: case study. Journal of Advanced Nursing, 72(7), 1638- 1653.

Lahti, M., Haapaniemi-Kahala, H. and Salminen, L. (2017) Use of social media by nurse educator students: an exploratory survey. The Open Nursing Journal, 11, 26-33.

Liberati, A., Altman, D.G., Tezlaff, J., Mulrow, C., Gotzsche, P.C., loannidis, J.P., Clarke, M., Devereaux, P.J., Kleijnen, J. and Moher, D. (2009) The PRISMA statement for reporting systematic reviews and meta-analyses of studies that evaluate health care interventions: explanation and elaboration. Journal of Clinical Epidemiology, 62(10). Available at: https://www.sciencedirect.com/science/article/pii/S0895435609001802 [Accessed 04 March 2019].

Lofters, A.K., Slater, M.B., Angl, E.N. and Leung, F.K. (2016) Facebook as a tool for communication, collaboration, and informal knowledge exchange among members of a multisite family health team. Journal of Multidisciplinary Healthcare, 1(9), 29-34.

Maloney, S., Moss, A. and Ilic, D. (2014) Social media in health professional education: a student perspective on user levels and prospective applications. Advances in Health Sciences Education, 19(5), 687-697.

National Institute for Health and Care Excellence. (2016) Social media strategy development: a guide to using social media for public health communication. London: NICE. 
Nedder, M.M., Levine, S.A., Galligan, C., Ryan Avery, K., Eagan-Bengston, E. and Reilly, K.M. (2017) Blogging as an innovative method of peer-to-peer educational sharing. Critical Care Nurse, 37(1), 1-9.

Nursing and Midwifery Council (NMC). (2018) The Code: professional standards of practice and behaviour for nurses, midwives and nursing associates. Updated ed. London: NMC.

Nyangeni, T., du Rand, S. and van Rooyen, D. (2015) Perceptions of nursing students regarding responsible use of social media in the Eastern Cape. Curationis, 38(2), 1-9.

O'Reilly, T. (2005) What Is Web 2.0? Design Patterns and Business Models for the Next Generation of Software. Available at https://www.oreilly.com/pub/a/web2/archive/what-isweb-20.html. Accessed on 22.7.19

Parahoo, K. (2014) Nursing research: principles, process and issues. $3^{\text {rd }}$ ed. London: Palgrave Macmillan.

Pimmer, C., Bruhlmann, F., Odetola, T.D., Dipeolu, O., Grohbiel, U. and Ajuwon, A.J. (2018) Instant messaging and nursing clinical learning experience. Nurse Education Today, 64(1), 119-124.

Price, A.M., Devis, K., LeMoine, G., Crouch, S., South, N. and Hossain, R. (2018) First year nursing students use of social media within education: results of a survey. Nurse Education Today, 61, 70-76.

Rindfuss, R.R., Choe, M.K., Tsuya, N.O., Bumpass, L.L. and Tamaki, E. (2015) Do low survey response rates bias results? Evidence from Japan. Demographic Research, 32(26), 797-828.

Ross, J.G. and Myers, S.M. (2017) The current use of social media in undergraduate nursing education: a review of the literature. Computers, Informatics, Nursing, 35(7), 338-344.

Sekaran, U. and Bougie, R. (2013) Research methods for business. $6^{\text {th }}$ ed. Chichester: John Wiley \& Sons Ltd. 
Sinclair, W., McLoughlin, M., Warne, T. (2015). To Twitter to Woo: Harnessing the power of social media (SoMe) in nurse education to enhance the student's experience. Nurse Education in Practice. 15 (6) : 507-11. doi: 10.1016/j.nepr.2015.06.002.

Stephens and Gunther (2016) Twitter, millennials, and nursing education research. Nursing Education Perspectives, 37(1), 23-27.

Tubaishat, A. (2018) Student nurses' perceptions of Facebook as an interactive learning platform in nursing education. Contemporary Nurse, 54(4-5), 456-471.

Tuckett, A. and Turner, C. (2016) Do you use social media? A study into new nursing and midwifery graduates' uptake of social media. International Journal of Nursing Practice, 22(2), 197-204.

Warshawski, S., Bar-Lev, O. and Barnoy, S. (2018) Role of academic self-efficiency and social support on nursing students' test anxiety. Nurse Educator, 44(1), 6-10.

Whittemore, R and Knafl, K. (2005) The integrative review: updated methodology. Journal of Advanced Nursing. 52(5), 546-553.

Williamson, G.R. and Whittaker (2017) Succeeding in literature reviews and research project plans for nursing students. $3^{\text {rd }}$ ed. London: SAGE Publications Ltd.

World Health Organisation. (2014) Disseminating the research findings. (NLM classification: W 20.5). Geneva: WHO. 
Table 1: Key words used in the search

\begin{tabular}{|l|l|l|}
\hline $\begin{array}{l}\text { social media OR web 2.0 OR } \\
\text { social network* OR twitter OR } \\
\text { facebook OR instagram OR } \\
\text { whatsapp OR mobile app* OR } \\
\text { youtube OR blog* }\end{array}$ & $\begin{array}{l}\text { nurs* education OR nurs* learning OR } \\
\text { nurs* teaching OR nurs* teaching tool } \\
\text { OR nurs training OR health* } \\
\text { professional* education OR health* } \\
\text { professional* learning OR health* } \\
\text { professional* teaching OR health* } \\
\text { professional* teaching tool or health* } \\
\text { professional* training }\end{array}$ \\
\hline
\end{tabular}

Table 2: Inclusion and exclusion criteria

\begin{tabular}{|l|l|}
\hline \multicolumn{1}{|c|}{ Inclusion criteria } & \multicolumn{1}{c|}{ Exclusion criteria } \\
\hline Published between 2014 and 2019 & Published prior to 2014 \\
\hline Available in English & $\begin{array}{l}\text { Published in another language other than } \\
\text { English }\end{array}$ \\
\hline Human Research & Secondary research \\
\hline Peer-reviewed academic journals & \\
\hline $\begin{array}{l}\text { Focused on social media in nurse and } \\
\text { health professional education }\end{array}$ & \\
\hline
\end{tabular}

Table 4: Key themes in the review

\begin{tabular}{|c|}
\hline Theme \\
\hline Communication and collaboration \\
\hline A source of reference \\
\hline Personal development \\
\hline Pitfalls of social media \\
\hline Ethical and moral issues \\
\hline
\end{tabular}



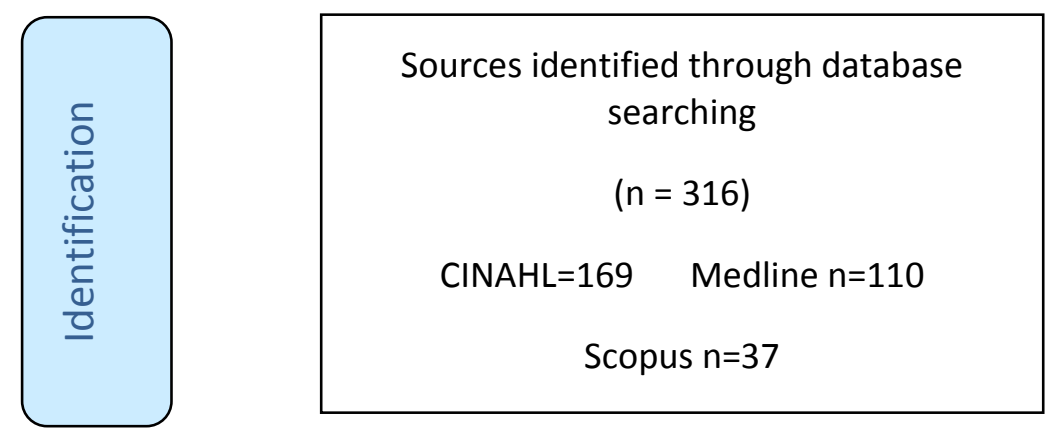

Additional records and professional documents identified through other sources $(n=0)$
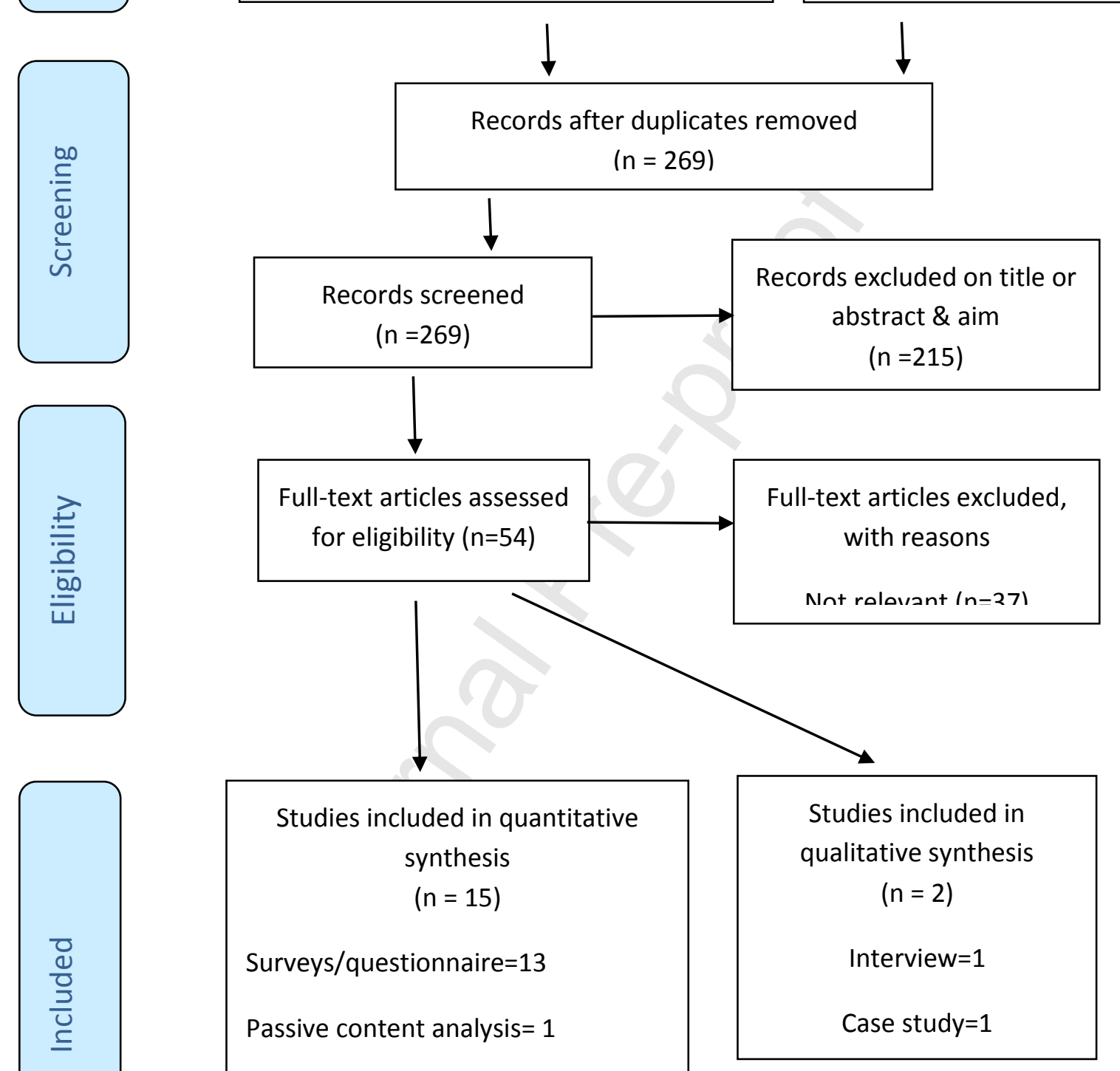

Web site search $=1$

Figure 1 PRISMA Search Results 
Table 3: Presentation of search findings from databases

\begin{tabular}{|c|c|c|c|c|c|}
\hline $\begin{array}{l}\text { Authors/ } \\
\text { Year }\end{array}$ & Title & Methodology & $\begin{array}{l}\text { Population/ } \\
\text { Samples }\end{array}$ & Setting & Relevance \\
\hline $\begin{array}{l}\text { Booth. } \\
2015\end{array}$ & $\begin{array}{l}\text { Happiness, } \\
\text { stress, a bit of } \\
\text { vulgarity, and } \\
\text { lots of } \\
\text { discursive } \\
\text { conversation: } \\
\text { a pilot study } \\
\text { examining } \\
\text { nursing } \\
\text { students' } \\
\text { tweets about } \\
\text { nursing } \\
\text { education } \\
\text { posted to } \\
\text { twitter }\end{array}$ & $\begin{array}{l}\text { Conventional } \\
\text { content } \\
\text { analysis; } \\
\text { passive } \\
\text { analysis }\end{array}$ & $\begin{array}{l}189 \text { tweets } \\
\text { from nursing } \\
\text { students }\end{array}$ & $\begin{array}{l}\text { Worldwide: } \\
\text { geographical } \\
\text { location } \\
\text { unknown as } \\
\text { information } \\
\text { gathered from } \\
\text { tweets via search } \\
\text { engine } \\
\text { socialmention.co } \\
\text { m }\end{array}$ & $\begin{array}{l}\text { Exploring how } \\
\text { students cope } \\
\text { with nursing } \\
\text { school; using } \\
\text { Twitter to } \\
\text { analyse } \\
\text { tweets }\end{array}$ \\
\hline $\begin{array}{l}\text { De Gagne } \\
\text { et al. } 2018\end{array}$ & $\begin{array}{l}\text { Social media } \\
\text { use and } \\
\text { cybercivility } \\
\text { guidelines in } \\
\text { US nursing } \\
\text { schools: a } \\
\text { review of } \\
\text { websites }\end{array}$ & $\begin{array}{l}\text { Descriptive } \\
\text { cross- } \\
\text { sectional, } \\
\text { and non- } \\
\text { experimental } \\
\text { website } \\
\text { search design }\end{array}$ & $\begin{array}{l}230 \text { nursing } \\
\text { school } \\
\text { websites }\end{array}$ & $\begin{array}{l}\text { Nursing schools } \\
\text { throughout the } \\
\text { United States of } \\
\text { America. }\end{array}$ & $\begin{array}{l}\text { Use, policies, } \\
\text { and guidelines } \\
\text { on social } \\
\text { media use }\end{array}$ \\
\hline $\begin{array}{l}\text { Duke et al. } \\
2017\end{array}$ & $\begin{array}{l}\text { Social media in } \\
\text { nurse } \\
\text { education: } \\
\text { utilization and } \\
\text { e- } \\
\text { professionalis } \\
\text { m }\end{array}$ & $\begin{array}{l}\text { Questionnair } \\
\mathrm{e}\end{array}$ & $\begin{array}{l}337 \text { nursing } \\
\text { students } \\
29 \text { nurse } \\
\text { faculty } \\
\text { members }\end{array}$ & $\begin{array}{l}\text { One nursing } \\
\text { school in Canada }\end{array}$ & $\begin{array}{l}\text { Exploration of } \\
\text { social media } \\
\text { use and } \\
\text { potential } \\
\text { professional } \\
\text { implications }\end{array}$ \\
\hline $\begin{array}{l}\text { Gagnon. } \\
2015\end{array}$ & $\begin{array}{l}\text { Using Twitter } \\
\text { in health } \\
\text { professional } \\
\text { education }\end{array}$ & $\begin{array}{l}\text { Pre and post } \\
\text { course } \\
\text { student } \\
\text { surveys }\end{array}$ & $\begin{array}{l}36 \text { physical } \\
\text { therapy } \\
\text { students }\end{array}$ & America & $\begin{array}{l}\text { Measures } \\
\text { overall social } \\
\text { media use, } \\
\text { and } \\
\text { perceptions of } \\
\text { Twitter in } \\
\text { health } \\
\text { professional } \\
\text { education }\end{array}$ \\
\hline $\begin{array}{l}\text { Jones et al. } \\
\text { 2016(a) }\end{array}$ & $\begin{array}{l}\text { To blog or not } \\
\text { to blog: what } \\
\text { do nursing } \\
\text { faculty think? }\end{array}$ & Survey & $\begin{array}{l}122 \text { nurse } \\
\text { educators }\end{array}$ & $\begin{array}{l}49 \text { schools of } \\
\text { nursing in Illinois } \\
\text { and } 38 \text { schools of } \\
\text { nursing in }\end{array}$ & $\begin{array}{l}\text { The use of } \\
\text { blogging in } \\
\text { nurse } \\
\text { education, }\end{array}$ \\
\hline
\end{tabular}




\begin{tabular}{|c|c|c|c|c|c|}
\hline & & & & Ontario & $\begin{array}{l}\text { identifying } \\
\text { subsequent } \\
\text { barriers of its } \\
\text { use }\end{array}$ \\
\hline $\begin{array}{l}\text { Jones et al } \\
\text { 2016(b) }\end{array}$ & $\begin{array}{l}\text { Introducing } \\
\text { Twitter as an } \\
\text { assessed } \\
\text { component of } \\
\text { the } \\
\text { undergraduate } \\
\text { nursing } \\
\text { curriculum: } \\
\text { case study }\end{array}$ & Case study & $\begin{array}{l}547 \text { nursing } \\
\text { students }\end{array}$ & $\begin{array}{l}\text { Plymouth } \\
\text { University, } \\
\text { United Kingdom }\end{array}$ & $\begin{array}{l}\text { Insight into } \\
\text { the } \\
\text { effectiveness } \\
\text { of adding } \\
\text { Twitter to } \\
\text { nursing } \\
\text { curriculum }\end{array}$ \\
\hline $\begin{array}{l}\text { Lahti et al } \\
2017\end{array}$ & $\begin{array}{l}\text { Use of social } \\
\text { media by } \\
\text { nurse } \\
\text { educator } \\
\text { students: an } \\
\text { exploratory } \\
\text { survey }\end{array}$ & Survey & $\begin{array}{l}49 \text { nurse } \\
\text { educator } \\
\text { students }\end{array}$ & $\begin{array}{l}\text { One university in } \\
\text { Finland }\end{array}$ & $\begin{array}{l}\text { Descriptions } \\
\text { of the use of } \\
\text { social media } \\
\text { in nurse } \\
\text { educators } \\
\text { education, } \\
\text { and how their } \\
\text { learning } \\
\text { needs are } \\
\text { linked to } \\
\text { social media }\end{array}$ \\
\hline $\begin{array}{l}\text { Lofters et } \\
\text { al. } \\
2016\end{array}$ & $\begin{array}{l}\text { Facebook as a } \\
\text { tool for } \\
\text { communicatio } \\
\mathrm{n} \text {, } \\
\text { collaboration, } \\
\text { and informal } \\
\text { knowledge } \\
\text { exchange } \\
\text { among } \\
\text { members of a } \\
\text { multisite } \\
\text { family health } \\
\text { team }\end{array}$ & Survey & $\begin{array}{l}26 \text { health } \\
\text { professionals }\end{array}$ & $\begin{array}{l}\text { One Family } \\
\text { Health Team in } \\
\text { Toronto, Ontario }\end{array}$ & $\begin{array}{l}\text { Evaluating } \\
\text { private } \\
\text { Facebook } \\
\text { group as an } \\
\text { aid to } \\
\text { improve } \\
\text { communicatio } \\
\mathrm{n} \text { and } \\
\text { collaboration }\end{array}$ \\
\hline $\begin{array}{l}\text { Maloney } \\
\text { et al. } \\
2014\end{array}$ & $\begin{array}{l}\text { Social media in } \\
\text { health } \\
\text { professional } \\
\text { education: a } \\
\text { student } \\
\text { perspective on } \\
\text { user levels and } \\
\text { prospective } \\
\text { applications }\end{array}$ & $\begin{array}{l}\text { Questionnair } \\
\mathrm{e}\end{array}$ & $\begin{array}{l}142 \\
\text { physiotherap } \\
\text { y students }\end{array}$ & $\begin{array}{l}\text { One university } \\
\text { campus in } \\
\text { Australia }\end{array}$ & $\begin{array}{l}\text { Health } \\
\text { professional } \\
\text { students' use } \\
\text { and } \\
\text { behaviours } \\
\text { associated } \\
\text { with social } \\
\text { networking } \\
\text { sites }\end{array}$ \\
\hline
\end{tabular}




\begin{tabular}{|c|c|c|c|c|c|}
\hline $\begin{array}{l}\text { Nedder et } \\
\text { al. } \\
2017\end{array}$ & $\begin{array}{l}\text { Blogging as an } \\
\text { innovative } \\
\text { method of } \\
\text { peer-to-peer } \\
\text { educational } \\
\text { sharing }\end{array}$ & Survey & $\begin{array}{l}37 \text { nursing } \\
\text { staff } \\
\text { members }\end{array}$ & $\begin{array}{l}\text { One hospital } \\
\text { ward (Cardiac } \\
\text { intensive care } \\
\text { unit) in Boston } \\
\text { Massachusetts }\end{array}$ & $\begin{array}{l}\text { Effectiveness } \\
\text { of blog use to } \\
\text { provide peer- } \\
\text { to- peer } \\
\text { sharing of } \\
\text { relevant } \\
\text { professional } \\
\text { education }\end{array}$ \\
\hline $\begin{array}{l}\text { Nyangeni } \\
\text { et al. } \\
2015\end{array}$ & $\begin{array}{l}\text { Perceptions of } \\
\text { nursing } \\
\text { students } \\
\text { regarding } \\
\text { responsible } \\
\text { use of social } \\
\text { media in the } \\
\text { Eastern Cape }\end{array}$ & $\begin{array}{l}\text { Semi- } \\
\text { structured } \\
\text { interviews }\end{array}$ & $\begin{array}{l}12 \text { nursing } \\
\text { students }\end{array}$ & $\begin{array}{l}\text { One nurse } \\
\text { education } \\
\text { programme in } \\
\text { South Africa }\end{array}$ & $\begin{array}{l}\text { Perceptions of } \\
\text { appropriate } \\
\text { social media } \\
\text { use within } \\
\text { nursing } \\
\text { students }\end{array}$ \\
\hline $\begin{array}{l}\text { Pimmer et } \\
\text { al. } \\
2018\end{array}$ & $\begin{array}{l}\text { Instant } \\
\text { messaging and } \\
\text { nursing } \\
\text { students' } \\
\text { clinical } \\
\text { learning } \\
\text { experience } \\
\end{array}$ & $\begin{array}{l}\text { Questionnair } \\
\mathrm{e}\end{array}$ & $\begin{array}{l}196 \text { nursing } \\
\text { students }\end{array}$ & $\begin{array}{l}\text { Five schools in } \\
\text { Oyo State, } \\
\text { Nigeria }\end{array}$ & $\begin{array}{l}\text { Student } \\
\text { nurses } \\
\text { experience of } \\
\text { WhatsApp use } \\
\text { in clinical } \\
\text { practice }\end{array}$ \\
\hline $\begin{array}{l}\text { Price et al. } \\
2018\end{array}$ & $\begin{array}{l}\text { First year } \\
\text { nursing } \\
\text { students use } \\
\text { of social media } \\
\text { within } \\
\text { education: } \\
\text { results of a } \\
\text { survey }\end{array}$ & $\begin{array}{l}\text { Cross- } \\
\text { sectional } \\
\text { survey }\end{array}$ & $\begin{array}{l}121 \text { nursing } \\
\text { students }\end{array}$ & $\begin{array}{l}\text { One university in } \\
\text { South East } \\
\text { England, United } \\
\text { Kingdom }\end{array}$ & $\begin{array}{l}\text { Evaluates the } \\
\text { use of social } \\
\text { media prior to } \\
\text { and upon } \\
\text { completion of } \\
\text { a pre- } \\
\text { registration } \\
\text { programme }\end{array}$ \\
\hline $\begin{array}{l}\text { Stephens } \\
\text { and } \\
\text { Gunther. } \\
2016\end{array}$ & $\begin{array}{l}\text { Twitter, } \\
\text { millennials, } \\
\text { and nursing } \\
\text { education } \\
\text { research }\end{array}$ & Survey & $\begin{array}{l}70 \text { nursing } \\
\text { students }\end{array}$ & $\begin{array}{l}\text { Two state- } \\
\text { supported } \\
\text { universities in } \\
\text { South-eastern } \\
\text { United States }\end{array}$ & $\begin{array}{l}\text { The use of } \\
\text { twitter as a } \\
\text { delivery } \\
\text { method of } \\
\text { nursing } \\
\text { research }\end{array}$ \\
\hline $\begin{array}{l}\text { Tubaishat. } \\
2018\end{array}$ & $\begin{array}{l}\text { Student } \\
\text { nurses' } \\
\text { perceptions of } \\
\text { Facebook as } \\
\text { an interactive } \\
\text { learning } \\
\text { platform in } \\
\text { nursing } \\
\text { education }\end{array}$ & $\begin{array}{l}\text { Pre-test and } \\
\text { post-test } \\
\text { questionnair } \\
\text { es }\end{array}$ & $\begin{array}{l}186 \text { nursing } \\
\text { students }\end{array}$ & $\begin{array}{l}\text { One public } \\
\text { university in } \\
\text { Jordan }\end{array}$ & $\begin{array}{l}\text { Student } \\
\text { nurses } \\
\text { experiences of } \\
\text { using } \\
\text { Facebook }\end{array}$ \\
\hline Tuckett & Do you use & Survey & 112 nurses & New Zealand and & Describes the \\
\hline
\end{tabular}




\begin{tabular}{|l|l|l|l|l|l|}
\hline $\begin{array}{l}\text { and Turner } \\
2016\end{array}$ & $\begin{array}{l}\text { social media? } \\
\text { A study into } \\
\text { new nursing } \\
\text { and midwifery } \\
\text { graduates } \\
\text { uptake of } \\
\text { social media }\end{array}$ & $\begin{array}{l}\text { and } \\
\text { midwives }\end{array}$ & Australia & $\begin{array}{l}\text { use of social } \\
\text { media in } \\
\text { professional } \\
\text { education of } \\
\text { new nursing } \\
\text { and midwifery } \\
\text { graduates }\end{array}$ \\
\hline $\begin{array}{l}\text { Warshaws } \\
\text { ki et al. }\end{array}$ & $\begin{array}{l}\text { Role of } \\
\text { academic self- } \\
\text { efficiency and } \\
\text { social support } \\
\text { on nursing } \\
\text { students' test } \\
\text { anxiety }\end{array}$ & $\begin{array}{l}\text { Self- } \\
\text { administered } \\
\text { questionnair } \\
\text { es }\end{array}$ & $\begin{array}{l}\text { 240 first and } \\
\text { fourth-year } \\
\text { nursing } \\
\text { students }\end{array}$ & $\begin{array}{l}\text { One } \\
\text { undergraduate } \\
\text { nursing } \\
\text { programme in } \\
\text { Israel }\end{array}$ & $\begin{array}{l}\text { Associations } \\
\text { between test } \\
\text { anxiety, self- } \\
\text { efficiency and } \\
\text { social support } \\
\text { from social } \\
\text { media }\end{array}$ \\
\hline
\end{tabular}

